\title{
The effect of oil price fluctuations on Spanish inflation
}

Luis Julián Álvarez, Isabel Sánchez and Alberto Urtasun

This article analyses the impact of changes in oil prices on the consumer price index (CPI) in the Spanish economy from a historical perspective. The evidence provided reveals a substantial degree of pass-through of these changes to CPI components tied to heating and vehicle fuel (direct effect).

However, the estimated effect of changes in crude prices on firms' input costs (indirect effects) and on inflation or wage expectations (second-round effects) is, on average, moderate.

Consequently, in the current situation, in the absence of fresh shocks in the expected path of oil prices, the rise in the CPI in early 2017 - linked to base effects prompted by the low price of this commodity for most of 2016 - can be expected to be essentially temporary and, therefore, consistent with a downward trajectory in inflation in the coming months. 
The authors of this article are Luis Julián Álvarez, Isabel Sánchez and Alberto Urtasun, of the Directorate General Economics, Statistics and Research.

Introduction

Channels of transmission
In recent months, crude prices have moved on a notably upward path which has led their year-on-year rate of change, calculated on the basis of their euro value, to stand at above $80 \%$ in January 2017. This is the highest increase in recent years, in stark contrast with the sharply negative rate of change at the beginning of 2016 (Chart 1). This quickening fed through to the Spanish consumer price index (CPI) which posted rates of increase of up to $3 \%$ in January and February 2017. Against this background, analysing the effect of oil price fluctuations on the trajectory of consumer prices is of particular interest.

From a historical perspective, increases in oil prices in the 1970s and 1980s led the price of this commodity to be considered as a prime source of global macroeconomic shocks. In particular, during those episodes, the rise in crude prices had a very pronounced contractionary impact on employment and activity in many developed economies. Furthermore, economic agents reacted by increasing prices and wages, in an attempt to counter the inevitable loss of income for many importing countries entailed by higher oil prices, which on some occasions triggered inflationary spirals.

However, the evidence built up during this century about the impact of crude price movements on activity and non-energy consumer prices indicates that the effects are generally expected to be notably smaller now ${ }^{1}$. The latter is seemingly explained by the absence of contemporaneity between bouts of sharp changes in crude prices and other commodity shocks (unlike in the 1970s), greater energy efficiency achieved at present and certain changes in the institutional environment and the operational framework of monetary policy. As for the latter, the main central banks' explicit commitment to price stability is expected to have contributed to anchoring agents' inflation expectations, resulting in a lower impact of temporary oil price changes on consumer prices.

This article offers evidence about the effects and channels of transmission of oil price changes on the growth of Spanish consumer prices. Following this introduction, the second section presents the different channels through which oil price changes are passed through to inflation and differences are drawn between the direct effects (third section), the indirect effects (fourth section) and the second-round and aggregate effects (fifth section).

The performance of oil prices in international markets is significant for analysing the inflation trajectory in terms of consumer prices for several reasons. First, household final consumption expenditure on oil-related items is significant $(6.1 \%$ according to current $\mathrm{CPI}$ weightings). Second, crude oil is a factor used in the production of goods and services by firms. Lastly, fluctuations in crude oil prices may impact, through their effects on expectations, on the determination of wages and business margins. The convergence of these factors makes the transmission of changes in oil prices to consumer prices a complex process, which calls for the different channels to be addressed separately.

1 See, inter alia, Hooker (2002) and Blanchard and Riggi (2013) for the United States; Blanchard and Galí (2007) for the G-7 countries; De Gregorio et al. (2007) for a broad range of industrialised and emerging countries; and Álvarez et al. (2011) and Gómez-Loscos et al.(2011) for the case of the Spanish economy. 


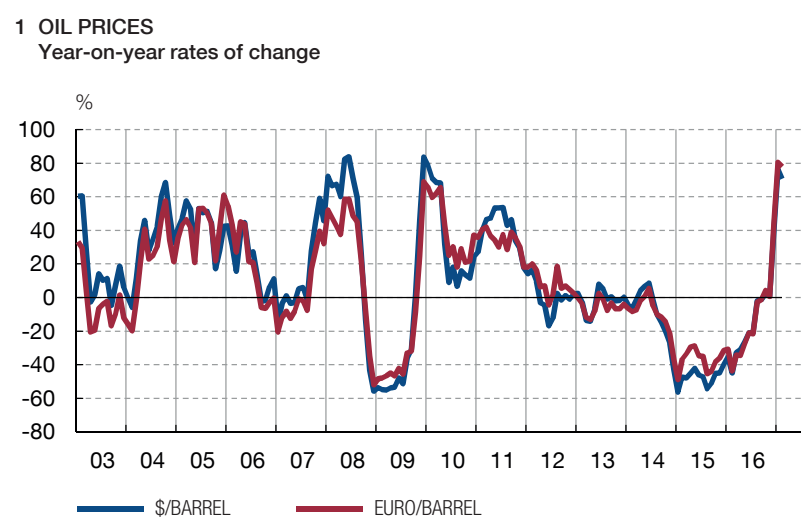
2 YEAR-ON-YEAR RATE OF CHANGE IN CPI AND CONTRIBUTIONS OF HEATING AND VEHICLE FUELS

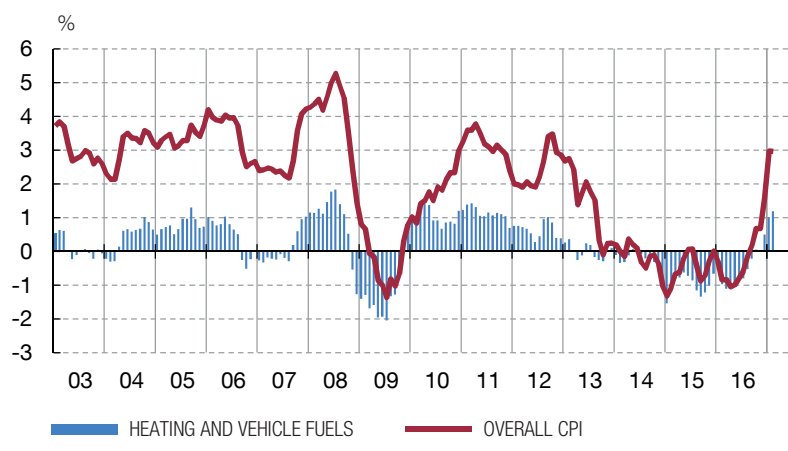

As for the first channel, there is a direct effect on consumer prices insofar as changes in oil prices feed through to the prices of oil derivatives consumed by households, such as vehicle and heating fuel. This transmission is generally very swift, as documented in the estimations presented below.

There is also an indirect effect since oil and derivatives are used as an additional input in different production processes. Consequently, sectors that employ technologies more intensive in the use of oil or its derivatives, such as refining or transportation, will be particularly affected by changes in their prices, given their greater impact on the costs of firms operating in these sectors. This indirect channel of transmission has a considerably slower pass-through speed than the previous one and its strength is generally more limited.

Finally, changes in oil prices can also trigger what is called second-round effects. Increases in final prices resulting from the above-mentioned direct and indirect effects may entail revisions of inflation expectations by pushing final prices higher once again if economic agents attempt to reduce their loss of real income by raising prices or wages. The higher prices of imported resources could prompt increases in non-energy prices set by firms, insofar as the latter try to counter the impact of greater costs on their income. Similarly, if in the wake of changes in crude oil prices and of their direct impact on the consumption basket of households, nominal wages were to increase, in an attempt to avoid a fall in compensation in real terms, firms' labour costs would rise, which could have an upward effect on retail prices. Likewise, in economies where indexation clauses are widespread, the initial increase in inflation would cause an additional effect when these clauses are triggered, which would mean that the effect on future inflation would be more persistent.

Changes in oil prices in international markets are reflected directly in heating and vehicle fuel prices (Chart 1). The contributions of these items to the overall price index fluctuate considerably, showing the movements in oil prices and, during specific episodes they may be of a notable size.

In order to determine the extent to which oil price changes pass through to consumer fuel prices, models are estimated below which permit the interaction of oil prices and their changes. Specifically, the functional form used [see Álvarez and Sánchez (2017)] is as follows: 


\begin{tabular}{|c|c|c|c|c|}
\hline & \multicolumn{2}{|c|}{ Vehicle fuel CPI } & \multicolumn{2}{|c|}{ Heating fuel CPI } \\
\hline & Coefficient & t-statistic & Coefficient & t-statistic \\
\hline Change in oil prices (t) & 0.093 & 2.9 & - & - \\
\hline Change in oil prices $(t-1)$ & 0.153 & 13.1 & 0.3 & 12.2 \\
\hline Contemporaneous interaction of oil prices & 0.003 & 5.0 & 0.0 & 14.0 \\
\hline
\end{tabular}

SOURCE: Banco de España.

1 ESTIMATED IMPACT OF AN INCREASE OF $10 \%$ IN OIL PRICES

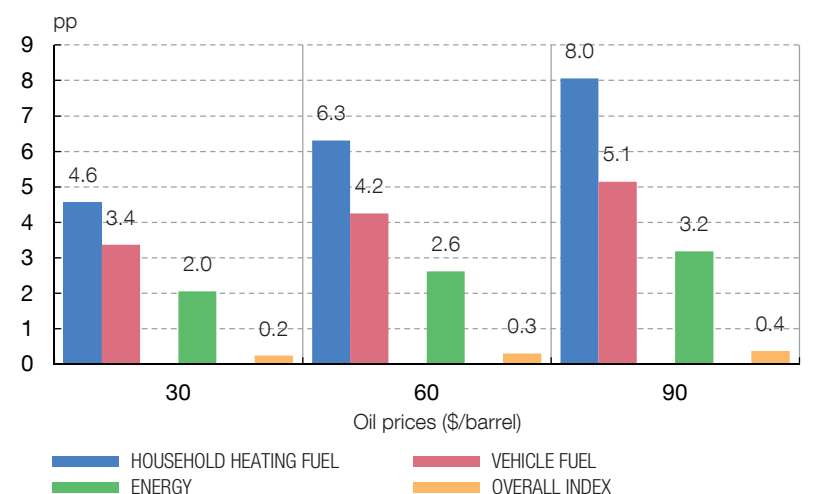

SOURCE: Banco de España.
2 PRICE INDEXES SENSITIVE TO OIL PRICES

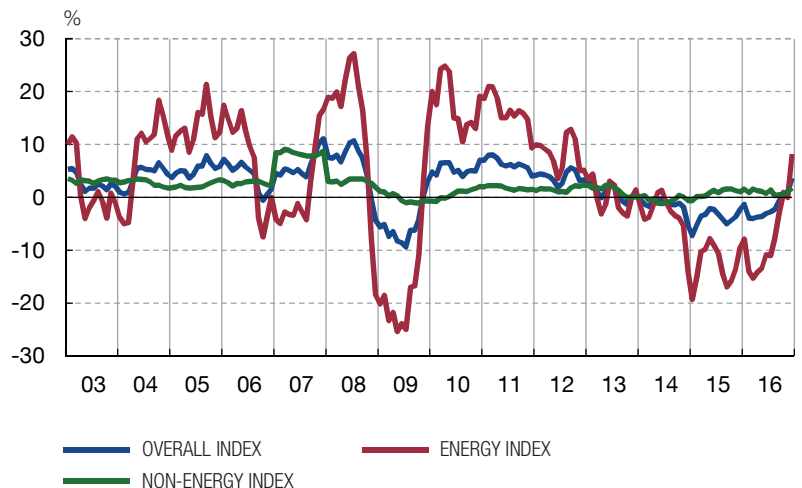

$\Delta P_{t}^{C}=\alpha \Delta P_{t}^{0}+\beta \Delta P_{t-1}^{0}+\gamma P_{t}^{0} \Delta P_{t}^{0}$

where $\Delta \mathrm{P}_{\mathrm{t}}^{\mathrm{C}}$ refers to the log change of the CPI in a specific month, $\Delta \mathrm{P}_{\mathrm{t}}^{0}$ to the log of the price of North Sea Brent oil expressed in euro and $\mathrm{P}_{\mathrm{t}}^{0}$ to its level ${ }^{2}$.

This simple empirical model, estimated with monthly data for the period 2002-2016, reveals that variations in crude are fed through to the $\mathrm{CPI}$ very rapidly, resulting in the impact materialising in the month of the shock and in the following month (Table 1). It was also detected that the elasticities are greater, the higher oil prices are (Chart 2). This shows, in particular, that the excise duties on fuels are of a fixed amount and, consequently, their relative importance changes when the final price does. For instance, if crude oil prices stand at $\$ 30$, an increase of $10 \%$ in oil prices ultimately means an increase of $0.2 \mathrm{pp}$ in the overall CPI. If crude oil prices were $\$ 60$, this increase would have an effect of $0.3 \mathrm{pp}$ on the overall index. The impact on the overall index would be $0.4 \mathrm{pp}$ with oil prices of $\$ 90$. By product, the elasticity of household heating fuel is greater than that of vehicle fuel.

Indirect effects on inflation
As mentioned earlier, the indirect effects arise as a consequence of the variations in firms' costs owing to the oil price changes which are higher for those activities that employ technologies more intensive in the use of oil or its derivatives. Transmission through this channel is logically slower than transmission of direct effects, and its impacts are more difficult to measure, consequently various empirical approaches are considered for estimating them.

2 As for the possible existence of asymmetries in the estimated relationship, Vendetti (2013) does not find that Spanish fuel prices vary differently to increases and decreases in crude oil prices. 
Estimated impact (percentage points)

\begin{tabular}{|c|c|c|c|}
\hline & \multirow[b]{2}{*}{2016 weightings } & \\
\hline & & $\begin{array}{c}\text { Contemporaneous } \\
\text { effect }\end{array}$ & Effect in six months (a) \\
\hline Overall index & 100.0 & 0.10 & 0.19 \\
\hline Unprocessed food & 7.5 & 0.00 & 0.16 \\
\hline Processed food & 15.3 & 0.00 & 0.02 \\
\hline Non-energy industrial & 24.8 & 0.00 & 0.03 \\
\hline Energy & 11.2 & 0.82 & 1.42 \\
\hline Services & 41.2 & 0.00 & 0.02 \\
\hline \multicolumn{4}{|l|}{ Memorandum item: } \\
\hline Non-energy CPI & 88.8 & 0.00 & 0.03 \\
\hline
\end{tabular}

Oil-sensitive price indices (b)

\begin{tabular}{lccc}
\hline Energy index & 6.7 & 2.50 & 3.91 \\
\hline Non-energy index & 12.9 & 0.08 & 0.14 \\
\hline Overall index & 19.7 & 0.00 & 1.23
\end{tabular}

SOURCE: Banco de España.

a Including cumulative effects after six months.

b Indices calcuated with sub-classes of CPI providing the basis for estimation of statistically significant effects of oil prices.

In order to approximate the size of these indirect effects, models were estimated for the 126 sub-classes of the CPI, the largest breakdown available for the period 2002-2016 [see Álvarez and Sánchez (2017)]. An equation ${ }^{3}$ was considered for each item, which includes oil prices contemporaneously and with lags of one up to six months. Specifically, the procedure used was as follows. First, those models, for which an effect significantly different from zero for oil prices was found, were selected from the models estimated. Second, the impacts estimated were aggregated using the weight of the different sub-classes in the overall index. The results of this procedure are summarised in Table 2 which presents the estimated impacts due to increases of $10 \%$ in oil prices. As can be seen, the effects on non-energy components are very low. Specifically, an increase in crude oil prices of $10 \%$ would mean, on average, an increase of $0.03 \mathrm{pp}$ in the non-energy CPI after six months. The greatest effects detected are on unprocessed food with an increase calculated at $0.16 \mathrm{pp}$ after six months

Similarly, based on the estimations made, three price indices were computed which are particularly sensitive to changes in oil prices (see Table 2 and Chart 2.2). These indices were calculated by aggregating the sub-classes of CPI for which a non-zero effect of oil prices was estimated. The items selected represent $19.7 \%$ of the total expenditure of the $\mathrm{CPI}, 6.7 \%$ of which is estimated to relate to heating and vehicle fuels and the remainder to non-energy items such as, for example, air transport and fish. In line with the findings discussed above and with the improvements in energy efficiency ${ }^{4}$, it can be seen that the effects on the non-energy components of changes in oil prices are limited. In particular, an increase of $10 \%$ in crude prices would lead to a rise of $0.12 \mathrm{pp}$ after six months in the nonenergy price index of this subgroup of goods which are relatively sensitive to oil.

3 In order to specify the models, which are estimated by maximum likelihood for the sample period 2002-2016, Gómez and Maravall's algorithm (2001) is used.

4 See Box 3.1 of Chapter 3 of the 2016 Annual Report of the Banco de España. 
1 SHORT-TERM INFLATION EXPECTATIONS (FUNCAS)

CUMULATIVE RESPONSE AFTER TWELVE MONTHS

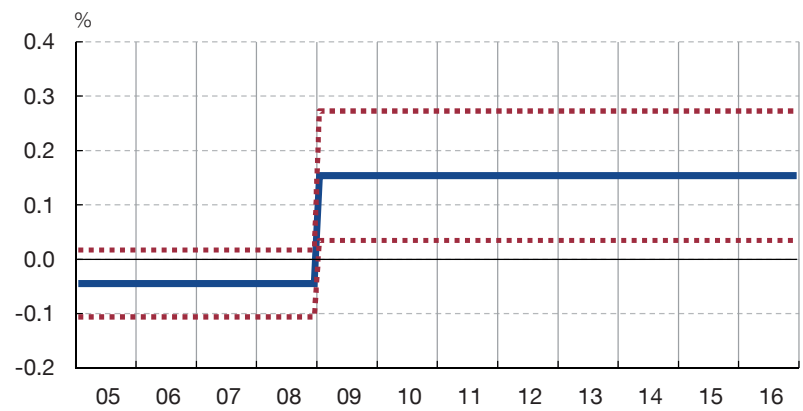

2 LONG-TERM EXPECTATIONS OF INFLATION (FIVE YEAR, FIVE YEAR) CUMULATIVE RESPONSE AFTER TWELVE MONTHS

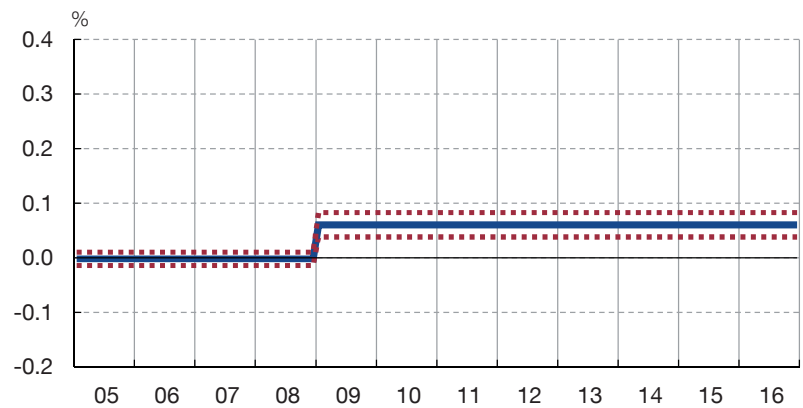

SOURCE: Banco de España.

a With their related 68\% confidence intervals (standard deviation). Used to estimate six-year moving windows in the period 1999-2016, and the average is taken in each period.

\section{Second-round and aggregate effects on inflation}

The impact on inflation of the direct and indirect effects described in the sections above may affect the expectations formation process of agents, giving rise to what is known as second-round effects. These effects may be bolstered, additionally, by the presence of indexation arrangements in relation to inflation, in the different contracts between economic agents.

For this reason, first, the possible link between inflation expectations and oil prices is analysed below, through the estimation of bivariate VAR models which study the overall developments in the two variables. These exercises are within the framework of recent literature which attempts to assess the sensitivity of inflation expectations to changes in macroeconomic variables ${ }^{5}$. In particular, two measures of expectations were considered: short-term inflation expectations, obtained with the Dovern et al. methodology (2012) based on a panel of forecasts by Funcas [Gil et al. (2017)], and long-term expectations of the five-year inflation rate five years ahead, obtained from the futures markets.

Chart 3 shows point estimates of the cumulative response after twelve months of each measure of inflation expectations to an oil price shock (short-term expectations in the left-hand panel and long-term ones in the right-hand panel). As can be seen in the chart, the response of the short-term measure was positive during the core period of the recent economic crisis, a time when agents' expectations relied to a greater degree on past inflation [see Álvarez et al. (2015)]. The estimated response of long-term expectations to changes in oil prices has risen since the onset of the crisis and is statistically significant, which could signal some deanchoring of these expectations at specific points in time $[\text { Draghi }(2014)]^{6}$. The combination, on one hand, of sharp falls in oil prices from 2014 onwards and, on the other, of a higher degree of sensitivity of inflation expectations to changes in these prices, have seemingly contributed to explaining why the rates of wage growth and inflation have remained very low in the recent period.

In order to analyse the pass-through of changes in oil prices to negotiated wage settlements ${ }^{7}$, which could give rise to second-round effects, it is useful to determine to

5 See, for example, Coibion and Gorodnichenko (2013) or Sussman and Zohar (2015). The pass-through of movements in short-term inflation expectations to long-term ones was subject to a special study [Cicarelli and Osbat (2017)].

6 If the expectations were anchored perfectly, their sensitivity to oil prices should be zero.

7 See Cuadrado et al. (2011). 


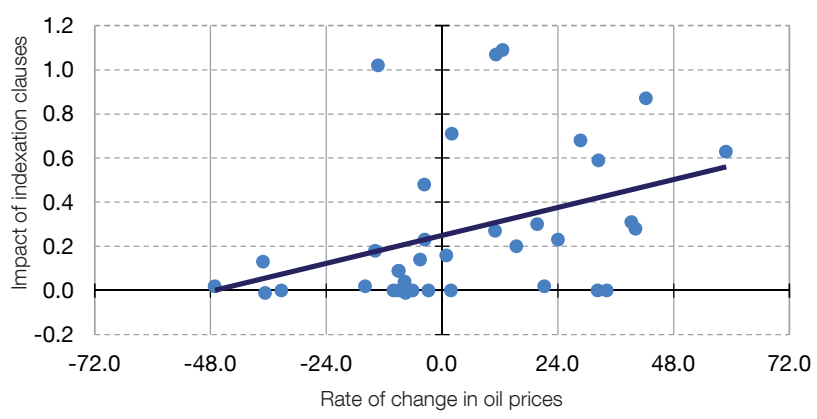

SOURCES: Ministerio de Empleo y Seguridad Social, INE and Banco de España.
2 PERCENTAGE OF WORKERS COVERED BY INDEXATION CLAUSES

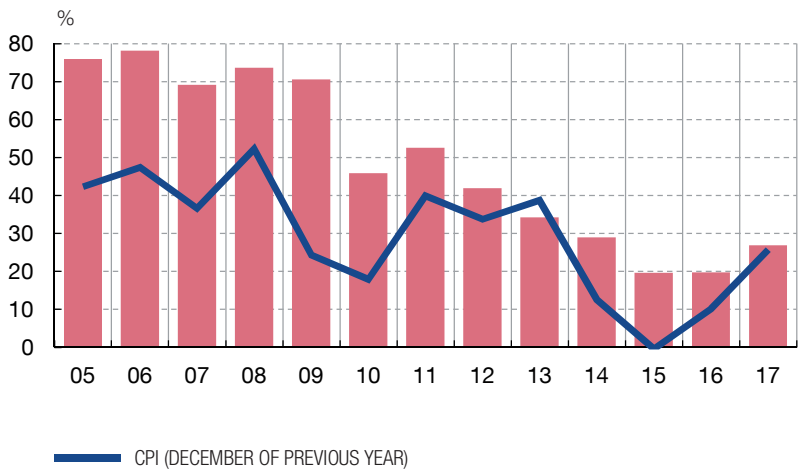

what extent wage rates respond to oil prices. As seen above, changes in oil prices affect inflation expectations which impacts wages negotiated in the current year. However, a feature of collective bargaining in Spain is its high inertia as a result of the weight of multi-year agreements. Also, these agreements frequently contain indexation clauses which are triggered when inflation, for whatever reason, exceeds the rate taken as a benchmark in the agreement. Most of the possible effect of higher crude oil prices on nominal wages is explained by the existence of indexation clauses. Chart 4.1 illustrates the relationship between the impact of these clauses and the rate of change in oil prices. Since inflation surprises are partly explained by the energy component, a close relationship is observed between the two variables. These clauses are mainly asymmetrical with the result that falls in crude oil prices do not feed through to revised wage rates.

After the crisis, the percentage of agreements with this type of clause has fallen, a phenomenon which has intensified in recent years in which the rate of change in the CPI has been negative (see Chart 4.2). Specifically, the percentage of agreements with this type of clause has decreased from around $80 \%$ in 2006 to $20 \%$ in 2016 , although on the latest information available to April 2017, the percentage of collective bargaining agreements with this clause is estimated to have increased to $26 \%$ in relation to the previous year, against a background of steep rises in inflation. Given the lower importance of this type of clause, it is expected that in the short term the operation of this channel for passing through oil price increases to nominal wages, and nominal wages to prices, will be more limited at present than in the past. Nevertheless, given the core role played by the recovery of competitiveness in the current growth phase of the Spanish economy, any excessive pass-through of higher energy prices to wages and business margins needs to be avoided.

Finally, it is necessary to be aware that the dynamics of oil price changes feeding through to consumer prices via indirect and second-round effects are influenced by the interactions of the former with other macroeconomic variables and prices in the economy, aside from those envisaged in the stylised analyses shown in the paragraphs above. To obtain a more comprehensive overview of these effects, which includes the aforementioned interactions, Table 3 provides simulations obtained with the Quarterly Macroeconometric Model of the Banco de España, which is documented in Hurtado et al. (2014). It is a linear estimated model for the main macro-aggregates of the Spanish economy and, therefore, includes 


\begin{tabular}{lccc} 
& Year t & Year $t+1$ & Year $t+2$ \\
\hline Harmonised index of consumer prices (HICP) & 0.4 & 0.0 & -0.1 \\
\hline Non-energy component of HICP & 0.0 & -0.1 & 0.0 \\
\hline Energy component of HICP & 3.2 & 0.3 & -0.1
\end{tabular}

SOURCE: Banco de España.

a Simulations performed with the Quarterly Macroeconometric Model of the Banco de España. Effect in percentage points.

average elasticities in accordance with historical experience. In particular, this table shows simulations of the effect on several price indices of an increase of $10 \%$ in crude oil prices. As can be seen, the effects on the overall CPI are significant, reflecting the direct impacts on fuel prices, in line with the results of the second section. The effect on the non-energy $\mathrm{CPI}$ is relatively small, which is estimated to be consistent with the limited role of indirect effects of changes in crude oil prices on inflation, in keeping with the evidence presented in the third section of this article.

\section{REFERENCES}

ÁLVAREZ, L. J., A. GÓMEZ LOSCOS and A. URTASUN (2015). "Asymmetries in the relationship between inflation and activity", Economic Bulletin, November, Banco de España.

ÁlVAREZ, L. J., S. HURTADO, I. SÁNCHEZ and C. THOMAS (2011). "The impact of oil price changes on Spanish and euro area consumer price inflation", Economic Modelling, 28(1), pp. 422-431.

ÁLVAREZ, L. J., and I. SÁNCHEZ (2017). A suite of inflation forecasting models, Occasional Paper 1703, Banco de España.

BANCO DE ESPAÑA (2016). "Quarterly report on the Spanish economy", Box 3, "The recent rise in inflation in Spain and the short-term outlook", Economic Bulletin, December.

BLANCHARD, O. J., and J. GALÍ (2007). "The Macroeconomic Effects of Oil Price Shocks: Why are the 2000s so different from the 1970s?", in International Dimensions of Monetary Policy, pp. 373-421, National Bureau of Economic Research, Inc.

BLANCHARD, O. J., and M. RIGGI (2013). "Why are the 2000s so different from the 1970s? A structural interpretation of changes in the macroeconomic effects of oil prices", Journal of the European Economic Association, 11(5), pp. 1032-1052.

CICCARELLI, M., and C. OSBAT (2017). Low inflation in the euro area: Causes and consequences, Occasional Paper Series, No 181, European Central Bank.

COIBION, O., and Y. GORODNICHENKO (2013). Is the Phillips curve alive and well after all? Inflation expectations and the missing disinflation, NBER Working Paper, No 19598.

CUADRADO, P., P. HERNANDEZ DE COS and M. IZQUIERDO (2011). «El ajuste de los salarios frente a las perturbaciones en España», Boletín Económico, February, Banco de España.

DE GREgoriO, J., O. LANDERRETCHE and C. A. NEILSON (2007). "Another Pass-through Bites the Dust? Oil Prices and Inflation", Economía, 7(2), pp. 155-208.

DOVERN, J., U. FRITSCHE and J. SLACALEK (2012). "Disagreement among forecasters in G7 countries", Review of Economics and Statistics, 94(4), pp. 1081-1096.

DRAGHI, M. (2014). Unemployment in the euro area. Speech by Mario Draghi, President of the ECB, Annual central bank symposium in Jackson Hole, 22 August.

GIL, M., J. J. PÉREZ and A. URTASUN (2017). "Macroeconomic uncertainty: measurement and impact on the Spanish economy", Economic Bulletin, 1/2017.

GÓMEZ, V., and A. MARAVALL (2001). "Automatic Modeling Methods for Univariate Series", in D. Peña, G. C. Tiao and R. S. Tsay (Eds.), A course in time series analysis, John Wiley \& Sons, Inc.

GÓMEZ-LOSCOS, A., A. MONTAÑÉS and M. D. GADEA (2011). "The impact of oil shocks on the Spanish economy", Energy Economics, 33(6), pp. 10701081.

HOOKER, M. (2002). "Are Oil Shocks Inflationary? Asymmetric and Nonlinear Specifications versus Changes in Regime", Journal of Money, Credit and Banking, 34 (2), pp. 540-561.

HURTADO, S., P. MANZANO, E. ORTEGA and A. URTASUN (2014). Update and re-estimation of the Quarterly Mode of Banco de España (MTBE), Occasional Paper 1403, Banco de España.

SUSSMAN, N., and O. ZOHAR (2015). Oil prices, inflation expectations, and monetary policy, Bank of Israe Discussion Paper, No 9.

VENDITTI, F. (2013). "From oil to consumer energy prices: how much asymmetry along the way?", Energy Economics, 40, pp. 468-473. 